\title{
THE ESTIMATION OF ADONIS VERNALIS POPULATIONS IN CHOSEN PATCHES OF LUBLIN UPLAND
}

\author{
${ }^{1}$ Bożena Denisow, ${ }^{2}$ Malgorzata Wrzesień, ${ }^{3}$ Anna Cwener
}

\author{
${ }^{1}$ Department of Botany, Laboratory of Horticultural Plants Biology, University of Life Sciences in Lublin, \\ Akademicka 15, 20-950 Lublin, Poland \\ e.mail: bozena.denisow@ar.lublin.pl \\ ${ }^{2,3}$ Department of Geobotany, Institute of Biology, Maria Curie-Skłodowska University, Akademicka 19, 20-033 Lublin, Poland \\ e.mail: ${ }^{2}$ mseptember@tlen.pl, ${ }^{3}$ acwener@wp.pl
}

Received: 15.09.2007

\section{S u m m a r y}

The number of Adonis vernalis populations, their size and abundance in xerothermic communities of the Lublin Upland have decreased significantly in the last 40-50 years, which indicates that there is a real risk of species extinction in the studied area. The paper is an attempt to indicate the possible factors which influence the decrease of Adonis vernalis populations. Detailed studies were carried out in six sites differing habitat conditions, land use and the size of Adonis vernalis populations. Observations were made of the abundance of blooming and the number of anthers per flower. The ability for reproduction was estimated indirectly by the mass of pollen delivered and its biological value. The populations of Adonis vernalis differ in number of anthers per flower ( $94.4-131.5$, on average), the mass of pollen delivered ( $0.83 \mathrm{mg}-3.18 \mathrm{mg}$ per 100 anthers, on average), the biological value of pollen and the size of pollen grains. Generally, stronger populations were characterized by better quality and a higher quantity of pollen. Potential energy of pollen in flowers from Pliszczyn and Łabunie was $69-72 \%$, compared to $36 \%-47 \%$ in the remaining populations. Grass burning did not cause a reduction of potential biological value of Adonis vernalis pollen. Xerothermic swards in Pliszczyn and Kąty regularly burnt developed strong, most abundant populations of Adonis vernalis with favorable pollen. The development of the shrub layer, if it is out of control, stands in the way of satisfactory reproduction of halophilous Adonis vernalis.

Key words: Adonis vernalis, populations, Lublin Upland, pollen grains viability, germination

\section{INTRODUCTION}

Species have wider or narrower ranges of distribution depending on habitat requirements. Adonis vernalis L. forms a pontic-panonnic subelement distributed in grassland communities in the south-east Europe steppe zone and is characteristic for different xerotermic swards of continental-submediterranean type, belonging to the order Festucetalia valesiaceae. In Poland it is a relict species of steppe zone flora. Its distribution is disjunct with some isolated growth places of extrazonal xerothermic habitats in the Lublin Upland, Małopolska, and the lower Warta or Wisła rivers ( G a w łow ska, 1956; Zając and Zając, 2001). Because of the small size of its populations, the disappearance of their habitats or a small number of locations, Adonis vernalis is a threatened element of the flora and is protected by law (Rozporządzenie ... 2004 ).

The stands of Adonis vernalis in the Lublin Upland are usually found on loose loam calcareous soils rich in $\mathrm{CaCO}_{3}$. The taxon occurs in patches of the Inuletum ensifoliae association, in community with Brachypodium pinnatum and Teucrium chamaedrys as well as on the edges of light pine-oak forests. Fijałkowski (1961) described in Lubelszczyzna (the Lublin region) 32 stations, including 8 with abundant populations composed of over one thousand individuals. On the next eight stations, the populations were slightly weaker and comprised 100-500 plants. The remaining populations were found in decline with approx. 5 individuals. The detailed biology of Adonis vernalis with an established model of vegetative organs was described by Jankowska-Błaszczuk (1995). Entomophilous, pollen yielding flowers of Adonis vernalis has been found valuable for bee-like hymenoptera because of the early blooming period (D e n i s o w and Wrzesień, 2006).

The aim of the study was to estimate chosen populations of Adonis vernalis in the Lublin Upland. Biological features of pollen grains were also analyzed. An attempt was made to indicate the possible factor causing variance in pollen grain features as well as in population size. 


\section{MATERIALS AND METHODS}

Study sites

A review of Adonis vernalis stations was carried out during vegetation seasons in 2004-2007 and was compared to literature (F i a łk ow s k i, 1961). The presumed reasons of different abundance of Adonis vernalis populations were analyzed. The study populations were located in the Lublin Upland at six different sites: in Łabunie (50³9”'N, 2325"E - GE 94), Chomęciska Małe $\left(50^{\circ} 48^{\prime} \mathrm{N}, 2^{\circ} 12^{\prime} \mathrm{E}\right.$ - GE72), Wólka Leszczańska $\left(51^{\circ} 02^{\prime} \mathrm{N}, 23^{\circ} 38^{\prime} \mathrm{E}-\mathrm{GE} 45\right)$, Stawska Góra $\left(51^{\circ} 13^{\prime} \mathrm{N}\right.$, $\left.23^{\circ} 25^{\prime} \mathrm{E}-\mathrm{GE} 23\right)$, Katy $\left(50^{\circ} 42^{\prime} \mathrm{N}, 23^{\circ} 04^{\prime} \mathrm{E}-\mathrm{GE} 81\right)$ and Pliszczyn $\left(51^{\circ} 18^{\prime} \mathrm{N}, 2^{\circ} 41^{\prime} \mathrm{E}-\mathrm{FE} 28\right)$ (Fig.1) - (Z a j a c , 1978). Habitat conditions were estimated separately for each station (slope inclination, soil, patch size) (Tab. 1).

The mean annual air temperature in the study region is $7.5^{\circ} \mathrm{C}$ with seasonal changes between monthly mean minimum $-4.5^{\circ} \mathrm{C}$ in January and monthly mean maximum temperature of $18.9^{\circ} \mathrm{C}$ in July. Annual average precipitation is $600-650 \mathrm{~mm}$ with humidity of $70 \%$. The period of vegetation totals between 200 and 210 days (Zinkiew ic z and Zinkiew ic z, 1973; Kaszews ki et al. 1995).

Table 1

Characteristics of chosen stations with Adonis vernalis L. in Lublin Upland.

\begin{tabular}{|l|c|c|c|}
\hline \multicolumn{1}{|c|}{ Stations } & $\begin{array}{c}\text { Patch size } \\
\mathrm{m}^{-2}\end{array}$ & Soil & Exposition \\
\hline Labunie & 1500 & redzina & $\mathrm{NE}$ \\
\hline Chomęciska & 200 & redzina & $\mathrm{S}$ \\
\hline Wólka Leszczańska & 500 & redzina & $\mathrm{N}$ \\
\hline Stawska Góra & 1000 & redzina & $\mathrm{W}$ \\
\hline Kąty & 1000 & brown & $\mathrm{SW}$ \\
\hline Pliszczyn & 1500 & brown & $\mathrm{S}$ \\
\hline
\end{tabular}

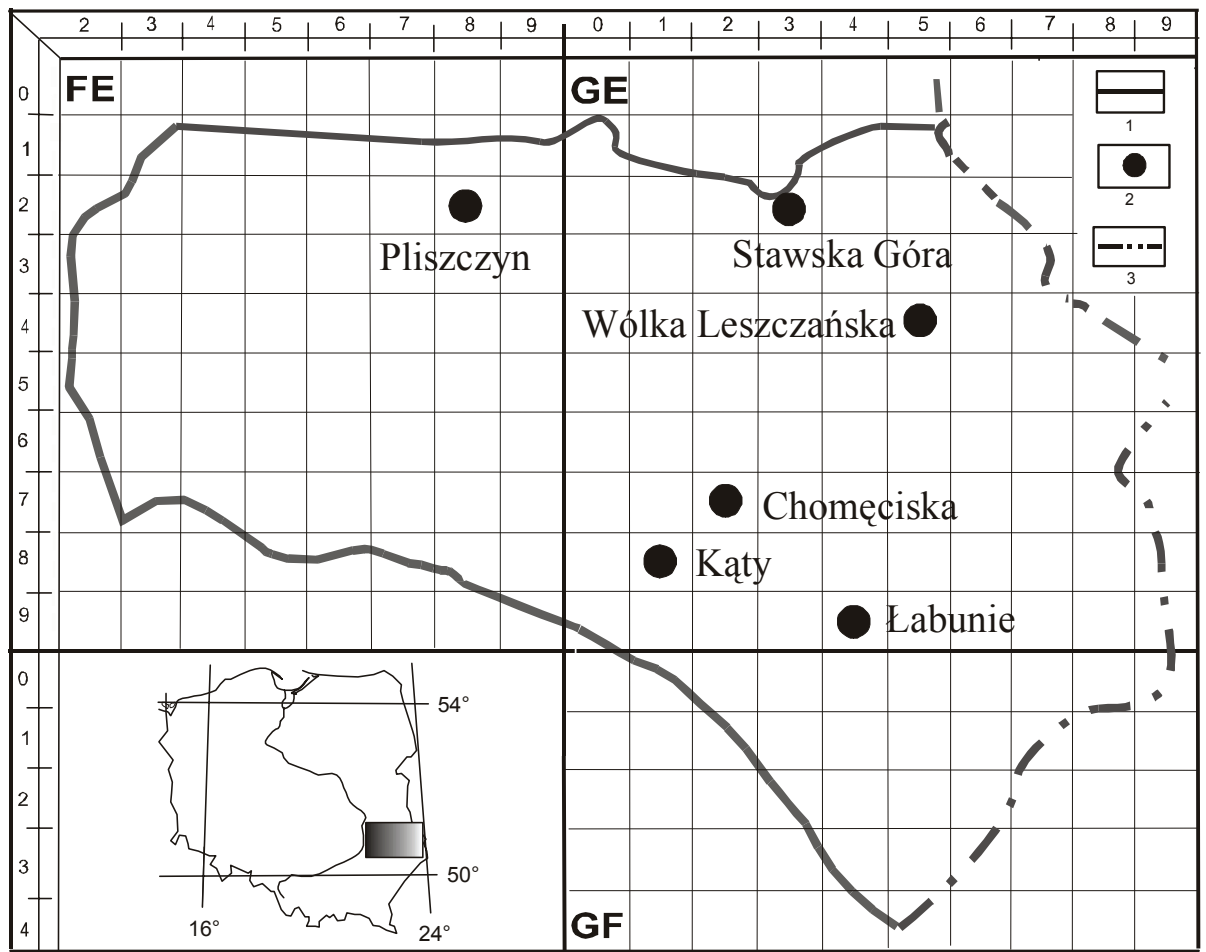

Fig. 1. Localization of Adonis vernalis L. stations against the background of ATPOL (10 km x $10 \mathrm{~km})$ (Zając, 1978), 1 - borders of the region, 2 - station, 3 - borders of the country. 


\section{Study methods}

The vegetation on each site was described according to Matuszkiewicz (2001). Special attention was paid to the land use in the area. Phenological observations concerning the duration of blooming were made (inter alios J a b ł o ń s k i and S z k l a n o w s ka, 1997). Additional detailed investigations of individuals were carried out. The number of individuals per square unit, abundance of blooming, number of anthers per flower, mass of pollen delivered by anthers and flowers were analyzed. The mass of pollen delivered was estimated according to $\mathrm{Szk}$ la n ow s k a method (1995). The anther size was determined on the basis of fresh and dry weight of 100 anthers. During the time of full blooming, closed, fully grown anthers from randomly chosen flower buds were isolated in a laboratory and separated from filaments. The anthers were placed in special glass containers (4 replications with 100 anthers for each side and year of study). The value of pollen was evaluated in terms of its viability in standard acetocarmin slides and germination after 24 hours in an agar medium with saccharose. The size of pollen, based on the length of polar and equatorial axis, was determined in glycerin jelly slides.

\section{Statistical analysis}

The relationship between the dry mass of anthers and the pure mass of delivered pollen was established using correlation coefficient (r). Statistical analyses concerning features of the androecium and pollen features were made. Data were subjected to one-way ANOVA. The significance of differences between means was tested by Duncan's test at $\alpha=0.05$.

\section{RESULTS}

Characteristics of xerotermic patches with Adonis vernalis. Variations of chosen populations between the stations and a comparison to previous studies are shown in Fig. 2. Unfortunately, on most stations the populations of Adonis vernalis declined substantially.

The population of Adonis vernalis in Labunie, which had been estimated as large as 6 thousands individuals back in 1961, had decreased significantly since then and was estimated at only 70 indiviluals with 1-5 flowering stamens each. Adonis vernalis grows on the edge of a loose light pine-oak forest situated on shallow rendzina soil (Fig. 3A). Conservation management is undertaken and branches of Cornus sanguinea, strongly developing in the undergrowth layer, are regularly hewn off. Other species sharing the patch are Primula veris, Brachypodium pinnatum, Carex michelii, Anemone sylvestris, Hepatica nobilis, Viola reichenbachiana, Peucedanum cervaria.

The xerothermic sward in Chomęciska Małe was located in an old stone pit. The population of Ado- nis vernalis is vanishing and in the period 2002-2007

it was estimated at 15 individuals, on average, that is three times less compared to literature data. Adonis vernalis is a component of the community developing on shallow rendzina soil in the old stone pit. Nowadays, the area is an illegal dumping ground. Brachypodium pinnatum, Teucrium chamaedrys, Peucedanum cervaria predominated on fragments of the patch. The process of overgrowing with Prunus spinosa and Rosa canina is far advanced.

The xerotermic grassland with Adonis vernalis in Wólka Leszczańska is limited to $400 \mathrm{~m}^{2}$ and located on ravine slopes neighboring fallow land (Fig. 3B). The shape and form of Adonis vernalis is similar to the population in Chomęciska Małe. Adult individuals form small clumps with only one up to a few flowers. The patch is composed of Brachypodium pinnatum, Teucrium chamaedrys, Peucedanum cervaria, Anemone sylvestris, Gallium boreale, Salvia pratensis, S. verticillata. The succession process is taking place and the growth of numerous Prunus spinosa bushes as well as Juniperus communis and Viburnum opulus is observed.

The xerotermic grasslands in the Stawska Góra nature preserve, near the town of Chełm, are connected with eroded chalky slopes of different inclination and covered with shallow rendzina. Apart from Adonis vernalis, the patch is composed of other typical xerothermic taxa such as Primula officinalis, Euphorbia cyparissias, Potentilla arenaria and it is clearly predominated by Brachypodium pinnatum, Anemone sylvestris and Aster amellus. The population of Adonis vernalis numbers ca. 100 individuals and has declined significantly comparing to literature data, as it was estimated at 3000 in 1961. The expansion of Prunus spinosa shrubs is well advanced.

The xerothermic patches in Kąty near Zamość occur on slopes of roads adjoining fields or on the south facing hill slopes covered with chalk and situated in the vicinity of light pine-oak forests edges. The population of Adonis vernalis, which numbered ca. 4000 individuals in 1961, is now estimated at ca. 100 clumps with a few to tens of flowers. Beside typical xerotermic species, such as Brachypodium pinnatum, Peucedanum cervaria, Salvia pratensis, Thalictrum minus, a few rare taxa were found, e.g. Linum flavum, Cerasus fruticosa, Peucedanum alsatica, Orchis purpurea and Orchis militaris. Year after year the vegetation was burnt down, especially in the spring time.

At the Pliszczyn site near Lublin, Adonis vernalis is a component of the Adonido-Brachypodietum pinnati community situated on a loess-covered slope of the Bystrzyca River valley with south inclination (Fig. 3C). The Adonis vernalis population, compared to literature data, is nearly constant and is estimated at ca. 1000 individuals. Shapely clumps of adult individuals produce tens of flowers. The xerothermic patch is 


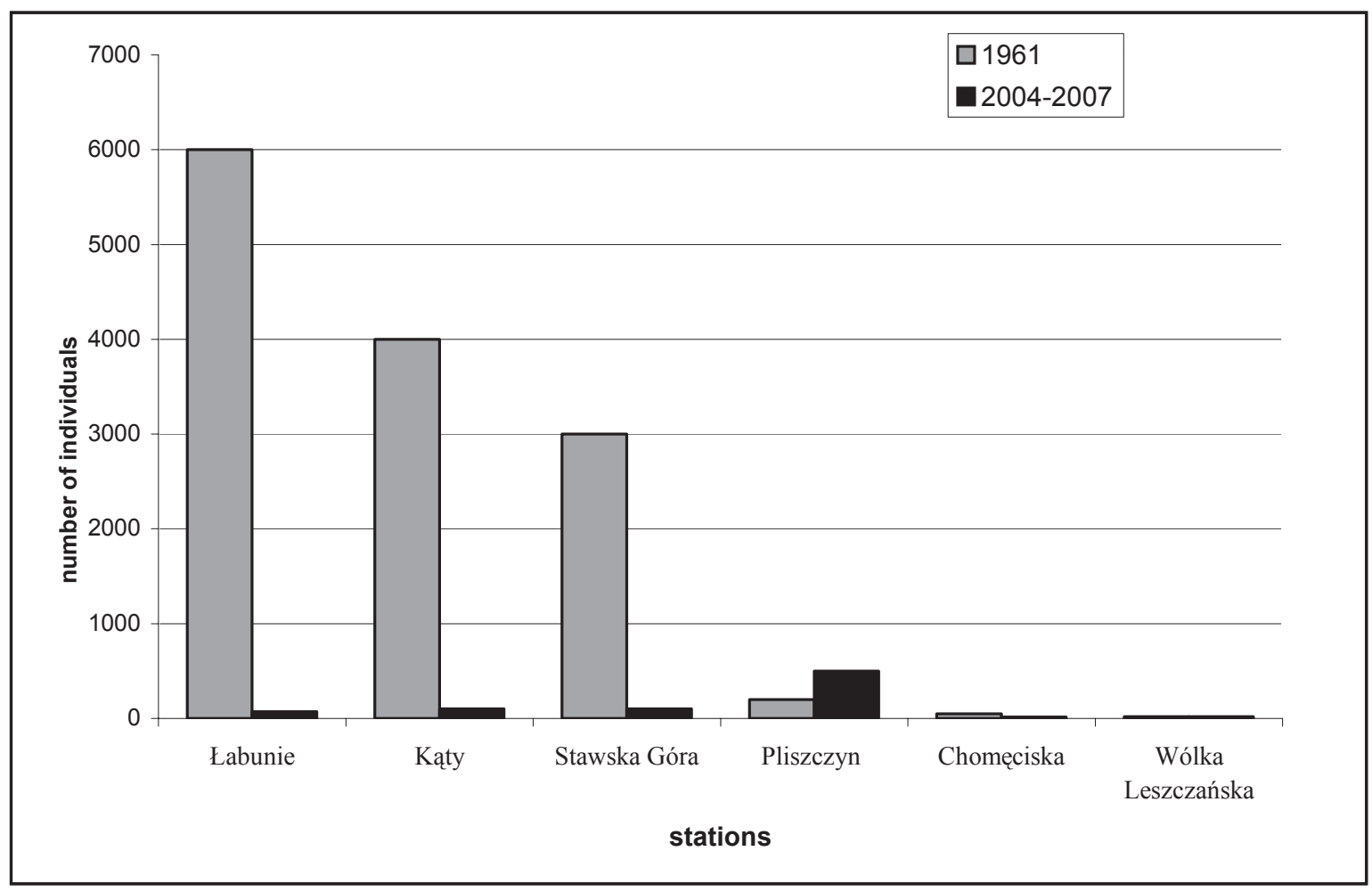

Fig. 2. Abundance of Adonis vernalis L. at chosen stations in Lublin Upland.

predominated by grass and meadow species (Medicago falcata, Brachypodium pinnatum, Gallium verum, Euphorbia cyparissias, Veronica spicata, Salvia pratensis, Phleum phleoides, Chamaecytisus ratisbonensis). The thermophilous vegetation in Pliszczyn is a fragmented island surrounded by arable fields and fallows. The area has been regularly burnt, usually in early spring.

The time and period of blooming were similar for the populations of Adonis vernalis under consideration (Fig. 4). The blooming of Adonis vernalis in the conditions of Lublin Upland occurred between the middle and the end of April. Every year, the blooming of the populations in Chomęciska Małe and Wólka Leszczańska was the shortest. The populations in Pliszczyn and Stawska Góra bloomed almost simultaneously and their blooming was the longest, lasting six weeks.

Pollen characteristics. The size and abundance of the Adonis vernalis populations under consideration were in close relation to the studied features of flowers and the biological value of pollen grains. Generally, stronger populations were characterized by better quality and a higher quantity of pollen. The anthers of Adonis vernalis are spirally arranged in the flower receptacle and their ripening is gradual. Great variability is characteristic of the number of stamens in the flowers of plants across the studied populations. The most abundant and vital populations in Pliszczyn and Katy develop flowers with the highest number of stamens (Tab. 2). Statistical- ly lower numbers of anthers were noticed in the flowers of Adonis vernalis from the sites at Wólka Leszczańska and Stawska Góra where the populations were found to be vanishing. At the same time, the decline in the number of individuals in both the abovementioned populations was substantial, compared to literature data. Significant differences in the fresh and dry mass of 100 anthers as well as in the amount of delivered mass of dry pollen were recorded between the populations (Fig. 5 ). The biggest anthers were found in the flowers from Katy, Łabunie and Pliszczyn. The fresh weight of 100 anthers, including pollen, was $48.9 \mathrm{mg}, 46.3$ and 42.9 , respectively. Also, an analysis of the relation of dry weight of anthers to fresh weight indicated that tissues of the anthers from the Katy and Pliszczyn sites were substantially better hydrated than of those from Łabunie. Interestingly, the dry weight of 100 anthers from Łabunie was $18.4 \mathrm{mg}$, on average, which was the highest, but at the same time the efficiency of the pollen producing archespore was the lowest, thus the mass of delivered pollen was only $2.6 \mathrm{mg}$ per 100 anthers. The mass of dry pollen delivered by anthers positively correlated with anther size $(r=0.64571)$ as well as with archespore efficiency. The worst developed anthers in the flowers at Wólka Leszczańska and Chomęciska Małe yielded 0.83 $\mathrm{mg}$ and $1.12 \mathrm{mg}$ of pollen, respectively. Significantly better developed anthers from the remaining sites delivered two-three times more pollen. 

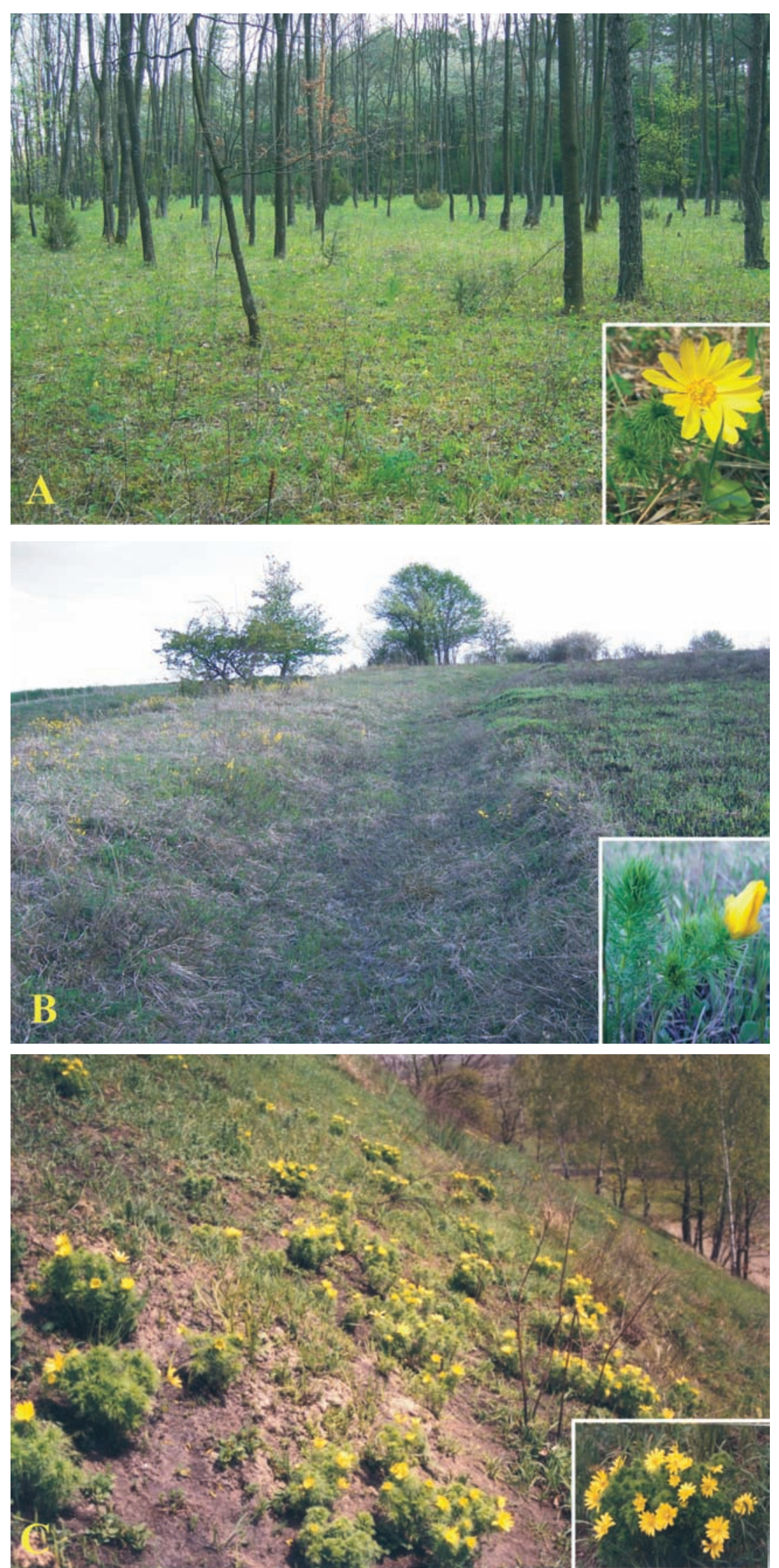

Fig. 3. The differentiation of chosen Adonis vernalis L. stations in Lublin Upland: A - Łabunie, B - Wólka Leszczańska, C - Pliszczyn. 


\begin{tabular}{|c|c|c|c|c|c|c|}
\hline \multirow{3}{*}{ Stations } & \multicolumn{6}{|c|}{ Months and decades } \\
\hline & \multicolumn{3}{|c|}{ IV } & \multicolumn{3}{|c|}{ V } \\
\hline & I & II & III & I & II & III \\
\hline \multicolumn{7}{|l|}{ Łabunie } \\
\hline \multicolumn{7}{|l|}{ Chomęciska } \\
\hline \multicolumn{7}{|l|}{ Wólka Leszczańska } \\
\hline \multicolumn{7}{|l|}{ Stawska Góra } \\
\hline \multicolumn{7}{|l|}{ Kąty } \\
\hline Pliszczyn & & & & & & \\
\hline
\end{tabular}

Fig. 4. The average time of Adonis vernalis L. blooming depending on the location in Lublin Upland. Stages of blooming $\square$ beginning full end

Table 2

The features of androecium and the mass of pollen delivered by different populations of Adonis vernalis $\mathrm{L}$.

\begin{tabular}{|l|ccc|ccc|}
\hline \multirow{2}{*}{ Stations } & \multicolumn{3}{|c|}{ Stamens per flower } & \multicolumn{3}{c|}{$\begin{array}{c}\text { Average mass of pollen } \\
\text { (mg) }\end{array}$} \\
\cline { 2 - 7 } & min & $\max$ & average & 100 anthers & \pm SD & 10 flowers \\
\hline Labunie & 105 & 126 & $117.6_{\mathrm{ab}}$ & $2.60_{\mathrm{b}}$ & 0.70 & 30.6 \\
Chomęciska & 94 & 123 & $110.5_{\mathrm{ab}}$ & $1.12_{\mathrm{a}}$ & 0.17 & 12.4 \\
Wólka Leszczańska & 87 & 100 & $94.4_{\mathrm{a}}$ & $0.83_{\mathrm{a}}$ & 0.13 & 7.8 \\
Stawska Góra & 75 & 134 & $106.5_{\mathrm{a}}$ & $2.39_{\mathrm{b}}$ & 0.42 & 25.4 \\
Kąty & 111 & 146 & $131.5_{\mathrm{b}}$ & $2.23_{\mathrm{b}}$ & 0.40 & 29.3 \\
Pliszczyn & 80 & 161 & $121.5_{\mathrm{b}}$ & $3.18_{\mathrm{c}}$ & 0.34 & 38.6 \\
\hline
\end{tabular}

means within columns referring to the same feature indicated with the same index are not significantly different at $\alpha=0.05$

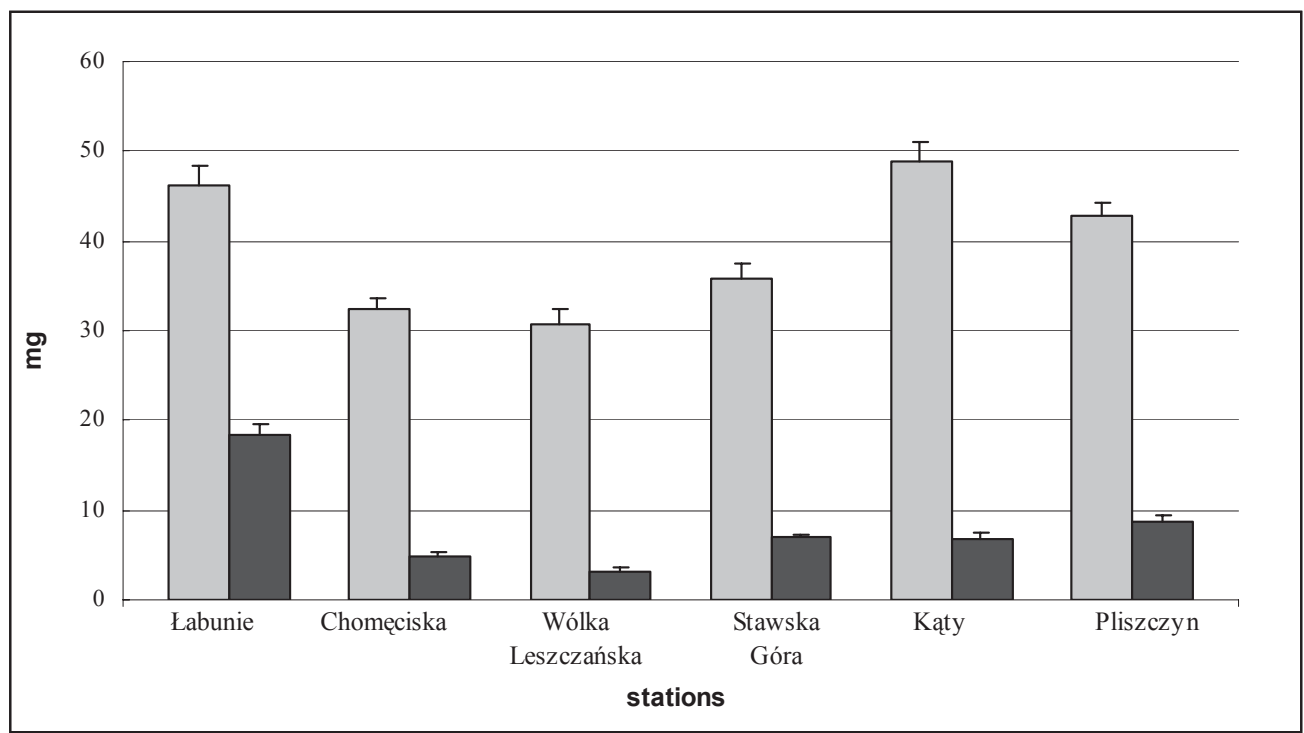

Fig. 5. Fresh $\square$ and $\square$ dry weight of 100 anthers with pollen in Adonis vernalis L. flowers depending on population location (averages from the years of study) $\pm \mathrm{SD}$ is given. 
Table 3

The biological value of pollen in flowers from different populations of Adonis vernalis $\mathrm{L}$.

\begin{tabular}{|l|ccc|}
\hline \multicolumn{1}{|c|}{ Stations } & $\begin{array}{c}\text { Pollen viability } \\
\%\end{array}$ & $\begin{array}{c}\text { Pollen germination } \\
\%^{*}\end{array}$ & $\begin{array}{c}\text { Potential energy } \\
\%^{* *}\end{array}$ \\
\hline Labunie & $98.35_{\mathrm{c}}$ & $36.23_{\mathrm{ab}}$ & 36.81 \\
Chomęciska & $75.00_{\mathrm{b}}$ & $27.32_{\mathrm{ab}}$ & 36.40 \\
Wólka Leszczańska & $42.57_{\mathrm{a}}$ & $16.27_{\mathrm{a}}$ & 38.22 \\
Stawska Góra & $47.21_{\mathrm{a}}$ & $22.63_{\mathrm{a}}$ & 47.88 \\
Kąty & $97.82_{\mathrm{c}}$ & $67.86_{\mathrm{c}}$ & 69.40 \\
Pliszczyn & $91.71_{\mathrm{c}}$ & $65.95_{\mathrm{c}}$ & 71.90 \\
\hline
\end{tabular}

* pollen germination investigated after 24 hours

${ }^{* *}$ pollen germination in relation to viability in $\%$

Table 4

The size of pollen grains of Adonis vernalis L. from different stations in Lublin Upland.

\begin{tabular}{|c|c|c|c|c|c|c|c|}
\hline \multirow{3}{*}{ Stations } & \multicolumn{6}{|c|}{ Length of axis } & \multirow{3}{*}{$\begin{array}{l}\text { Coefficient } \\
\text { P/E }\end{array}$} \\
\hline & \multicolumn{3}{|c|}{ polar } & \multicolumn{3}{|c|}{ equatorial } & \\
\hline & $\min$ & $\max$ & average & $\min$ & $\max$ & average & \\
\hline Łabunie & 20.8 & 23.5 & $20.5_{a}$ & 17.0 & 23.0 & $17.8 \mathrm{a}$ & 1.15 \\
\hline Chomęciska & 20.5 & 24.5 & $21.0_{\mathrm{a}}$ & 16.2 & 22.3 & $18.0_{\mathrm{a}}$ & 1.17 \\
\hline Wólka Leszczańska & 21.5 & 23.8 & $21.5_{\mathrm{ab}}$ & 17.5 & 24.0 & $19.0_{\mathrm{a}}$ & 1.13 \\
\hline Stawska Góra & 23.6 & 25.8 & $21.8_{\mathrm{ab}}$ & 17.5 & 23.1 & $18.5_{\mathrm{a}}$ & 1.17 \\
\hline Kąty & 23.5 & 26.5 & $24.5_{b}$ & 19.5 & 24.0 & $21.5_{\mathrm{ab}}$ & 1.14 \\
\hline Pliszczyn & 24.3 & 27.1 & $25.6_{c}$ & 21.3 & 24.3 & $22.9_{\mathrm{ab}}$ & 1.12 \\
\hline
\end{tabular}

The biological value of pollen was estimated on the basis of viability and germination (Tab. 3). The quality of pollen and the population sizes were interdependent. The observed differences between the populations, as far as the biological value of pollen is concerned, were with high probability caused by external factors. The strongest populations at Pliszczyn and Katy were characterized by the highest viability together with the highest pollen germination. The average viability was $91.7 \%$ and $97.8 \%$, respectively, while germination ability over $65 \%$. The relatively weak population at the Labunie station with high viability of pollen grains had very low germination ability, only $36 \%$. The remaining studied populations of Adonis vernalis delivered pollen with significantly lower viability and potential for effective fertilization with pollen tube formation. The germination of pollen grains was as low as $16.2-27 \%$.
The lowest size of pollen grains was found in the Łabunie, Chomęciska Małe and Wólka Leszczańska populations (Tab. 4). An average $\mathrm{P}$ diameter ranged $20.5-21.5 \mu \mathrm{m}$ and $\mathrm{E}$ diameter $17.8-19.0 \mu \mathrm{m}$. The biggest pollen grains were found at the Pliszczyn site $(\mathrm{P}=25.6 \mu \mathrm{m}, \mathrm{E}=22.9 \mu \mathrm{m})$. A lot of pollen grains from Wólka Leszczańska and Stawska Góra were mis-shapen, degenerate, which was probably associated with their high sterility.

\section{DISCUSSION}

The paper undertakes an attempt to find the possible factor which caused the significant limitation in abundance of Adonis vernalis plant populations at the chosen stations from the Lublin Upland. The decrease in individuals, compared to data published by $\mathrm{Fij}$ a 1 k o w s k i (1961), was found to be noticeably important 
in the case of four out of six studied populations. Thus, it is highly important to emphasize the necessity of Adonis vernalis conservation. The relatively stable structure of individuals in the populations from Pliszczyn and Katy shows that they found favorable conditions for development within the covered areas.

In principle, a correlation between the external factors and land management at the stations with Adonis vernalis, as well as the quality and quantity of pollen delivered and the population size and abundance, was confirmed.

J a nk ow ska - B łas zczuk (1995) reported that Adonis vernalis is a perennial that reproduces mainly generatively. In our study we estimated only the potential for generative reproduction on the basis of pollen grain features. It is widely accepted that biological features of pollen influence sexual reproduction (e.g. Ś n i e ż k o, 1991). Our results corroborate the opinion of other authors (e.g. Mulcahy and Mulcahy, 1987) that external factors influence the functionality of pollen. We found the biological value of pollen and its abundant mass delivered by anthers to be satisfactory only in flowers from the vital populations at Pliszczyn and Katy. Additionally, both populations had flowers with the most satisfactorily developed androecium with high efficiency of archesporial tissues. The xerothermic swards there were regularly burnt and represent good fragments of thermophilous vegetation. Unfortunately, the other populations at Chomęciska and Wólka Leszczańska with spring burning and shrub succession under control had individuals with the androecium delivering pollen of low quality and quantity. Possibly the differences found are more in connection with some external factors than grass burning practices.

The station at Stawska Góra was an example of degraded grasslands, invaded by the expansion of different shrubs, mainly Prunus spinosa, Frangula alnus, Rhamnus cathartica and Cornus sanguinea. Adonis vernalis there is in strong competition for light and probably water supplies which may influence the pollen production of halophilous taxa. Similar conditions in the Łabunie reserve with secondary succession changed the xerothermic sward into a light pine forest. The lack of light seems to be a limiting factor for Adonis vernalis development there.

Generally, our observations indicate that individuals in populations of Adonis vernalis pollinated with pollen of high viability and ability for pollen tube formation set abundant clumps, whereas pollination with pollen of low germination and potential energy was characteristic for weak populations. It corresponds with numerous observations demonstrating that pollen with low germination influence disadvantageously the final effect of pollination (Ś n i e ż k o, 1991).

\section{CONCLUSIONS}

1. The abundance and size of Adonis vernalis populations in the xerothermic patches of the Lublin Upland have decreased significantly in the last $40-50$ years. The threat of their extinction in the studied area is real.

2. The populations of Adonis vernalis differ in androecium development, the mass of pollen delivered by anthers and flowers, the biological value of pollen and the size of pollen grains.

3. Grass burning did not cause a reduction of potential biological value of Adonis vernalis pollen. The xerothermic swards in Pliszczyn and Katy regularly burnt developed strong, most abundant populations of Adonis vernalis with favorable pollen.

4. The development of the shrub layer, if it is out of control, stands in the way of satisfactory reproduction of halophilous Adonis vernalis. The biological value of pollen decreased significantly in every population with a considerable light shortage.

5. Thermophilous vegetation of the Lublin Upland deserves conservation as a source of rare and protected taxa.

\section{REFERENCES}

Fijałkowski D., 1961. Miłek wiosenny (Adonis vernalis L.) w województwie lubelskim. / Sweet vernal (Adonis vernalis L.) at Lublin Upland. Ann. UMCS sect. C. 16 (3): 49-74

Denisow B., Wrzesień M., 2006. The study of blooming and pollen efficiency of Adonis vernalis L. in xerothermic plant communities. J. Apicultural Sci. 50 (1): 25-32.

Gawłowska J., 1956. Miłek wiosenny (Adonis vernalis L.). / Sweet vernal (Adonis vernalis L.). Chroń. Przyr. Ojcz. 12, 3: 11-21

Jabłoński B., Szklanowska K., 1997. Wpływ niektórych czynników pogody na kwitnienie, nektarowanie, pylenie i oblot przez owady zapylające entomofilnych roślin uprawnych. W: Biologia kwitnienia, nektarowania i zapylania roślin. / The influence of some weather factors on blooming, nectar secretion, pollen presentation and pollinators forage on entomophilous crop plants. In: Blooming biology, nectar secretion and plants pollination. LTN, Lublin.

Jankowska-Błaszczuk M., 1995. Biologia populacji miłka wiosennego Adonis vernalis L. w rezerwacie „Skowronno". / The biology of a population of Adonis vernalis in the „Skowronno" nature preserve. Ochr. Przyr. 52: 47-58.

Kaszewski B., Mrugała S. Warakomski W., 1995. Klimat. Środowisko przyrodnicze Lubelszczyzny. / Climate. The natural environment of the Lublin region. ( R. Turski i S. Uziak red.), LTN, Lublin.

Matuszkiewicz W., 2001. Przewodnik do oznaczania zbiorowisk roślinnych Polski. / Guide for identification of 
Poland's plant communities. Guidebook Series 1. Wyd. Nauk. PWN, Warszawa.

Mulcahy D. L., Mulcahy G.B., 1987. The effect of pollen competition. Amer. Sci. 75: 44-50.

Rozporządzenie Ministra Środowiska z dnia 9 lipca 2004 w sprawie dziko występujących roślin objętych ochroną / Regulation of the Minister of Environment of 9 July 2004 on protected wild plants. (Dz. U. Nr 168, poz. 1764).

Szklanowska K., 1995. Pollen flow of crowfoot family (Ranunculaceae L.) from some natural plant communities. In: Changes in Fauna of Wild Bees in Europe. Banaszak ed., Pedagogical Univ., Bydgoszcz: 201- 209.

Śnieżko R., 1991. Pylniki i pyłek w hodowli in vitro. / Anthers and pollen in in vitro cultivation. Wiadomości botaniczne, 35 (1): 23-33.

Zając A., 1978. Założenia metodyczne „Atlasu rozmieszczenia roślin naczyniowych w Polsce. / Methodological assumption of Distribution Atlas of Vascular Plants in Poland. Wiadomości botaniczne. 22 (3): 145-155.

Zając A., Zając M. (eds). 2001. Atlas rozmieszczenia roślin naczyniowych w Polsce. / Distribution Atlas of Vascular Plants in Poland. Pracownia Chorologii Komputerowej Instytutu Botaniki UJ Kraków: 29.

Zinkiewicz W., Zinkiewicz A., 1973. Stosunki klimatyczne województwa lubelskiego. / Climatic relations of the Lublin region. Ann. UMCS, sect. B, 28: 139-202.

\section{Ocena stanu populacji milka wiosennego (Adonis vernalis L.) na wybranych stanowiskach Wyżyny Lubelskiej}

\section{Streszczenie}

W okresie ostatnich 40-50 lat liczba stanowisk oraz liczebność i wielkość populacji miłka wiosennego na Wyżynie Lubelskiej znacznie się zmniejszyła, co wskazuje na realne zagrożenie wyginięciem tego gatunku w zbiorowiskach kserotermicznych na tym obszarze. W pracy podjęto próbę wskazania potencjalnych czynników powodujących spadek zasobności populacji Adonis vernalis L. Szczegółowe badania prowadzono na sześciu wybranych stanowiskach różniących się warunkami siedliskowymi, sposobami użytkowania, a przede wszystkim wielkością populacji miłka wiosennego. Badano obfitość kwitnienia, liczbę pylników w kwiatach, a do oceny zdolności reprodukcyjnych posłużono się metodą pośrednią oceniając ilość i jakość dostarczanego pyłku.

Badane populacje różniły się liczbą pręcików wytwarzanych w kwiatach (średnio 94.4 - 131.5), masą dostarczanego pyłku $(0.83 \mathrm{mg}-3.18 \mathrm{mg}$ ze 100 pręcików), wartością biologiczną pyłku oraz wielkością ziaren pyłku. Witalne populacje wytwarzały więcej pyłku o wyższej żywotności i zdolności kiełkowania. Potencjalna energia kiełkowania pyłku wytwarzanego w kwiatach populacji z Pliszczyna i Łabuń wynosiła $69-72 \%$, a w pozostałych tylko $36 \%-47 \%$. Porównania jakości pyłku, warunków siedliskowych i sposobów użytkowania pozwalają stwierdzić, że wypalanie muraw stosowane na wiosnę nie wpływało negatywnie na potencjał biologiczny pyłku miłka wiosennego. Natomiast pozostawiony bez kontroli rozwój warstwy krzewów wpływa niekorzystnie na rozwój populacji światłolubnego gatunku jakim jest Adonis vernalis. 
